Volume 1, No. 1, Juni 2018

\title{
KOMUNIKASI POLITIK POLRI PADA ERA REFORMASI
}

\author{
Evie Ariadne Shinta Dewi \\ Dosen Fakultas Ilmu Komunikasi, Universitas Padjadjaran \\ evie@unpad.ac.id
}

\begin{abstract}
The topic of this article attempts to examine the Indonesian National Police from the perspective of Political Communication with the proposition that although the police are a law enforcement agency, its performance-through communications activities-can have sociological and political influence both locally, nationally and even regional and global. Moreover, if it refers to Peter Berger \& Thomas Luckmann's idea where reality is built socially, then the performance of the Police is in line with its core tasks because it creates public order and safeguards is not articulated in a vacuum circumstances, but in the midst of an active society and dynamic. It is what the meant as sociological and political aspects. It's a Qualitative descriptive study with desk research type which data collected using various sources in the form of documentation studies both hard copy and soft copy obtained in the library or online media. The analysis is done by using political communication concepts. The results of the study show that: firstly, the police institution in the context of social politics has the role of democracy guardian, secondly, police institutions are required to build harmonious political communications with other state institutions, especially with the House of Representatives (DPR) and the Corruption Eradication Commission (Komisi Pemberantasan Korupsi) KPK), and the third is police institutions are required to maintain the positive image of the institution by improving and improving the quality of Human Resources $(H R)$ and enforcement of the integrity of the apparatus.
\end{abstract}

\section{Key Words: Democracy, Political Communication, POLRI, Reform}

\begin{abstract}
Abstrak
Topik artikel ini berusaha mengkaji Kepolisian Republik Indonesia dari perspektif Komunikasi Politik dengan proposisi bahwa kendatipun kepolisian adalah lembaga (penegak) hukum, kinerjanya -melalui aktivitas komunikasi- dapat menimbulkan pengaruh sosiologis dan (juga) politik, baik pada skala lokal, nasional maupun regional bahkan global. Selain itu, jika merujuk pada pemikiran Peter Berger \& Thomas Luckmann dimana realitas dibangun secara sosial, maka kinerja Polri sesuai dengan tugas pokoknya -yakni menciptakan ketertiban umum dan menjaga keamanan- tidak terartikulasikan di dalam ruang hampa, melainkan di tengah-tengah masyarakat yang aktif dan dinamis inilah yang dimaksud dengan aspek sosiologis dan politik. Kajian deskriptif kualitatif dengan tipe desk research ini menggunakan berbagai sumber data berupa studi dokumentasi baik hard copy maupun soft copy yang diperoleh di perpustakaan maupun media online. Analisis dilakukan dengan mengunakan konsepkonsep komunikasi politik. Hasil kajian menunjukkan bahwa: pertama lembaga kepolisian dalam konteks social politik memiliki peran sebagai democracy guardian (penjaga demokrasi), kedua lembaga kepolisian dituntut membangun komunikasi politik yang harmonis dengan lembaga-lembaga negara lainnya terutama dengan Dewan
\end{abstract}


Perwakilan Rakyat (DPR) dan Komisi Pemberantasan Korupsi (KPK), ketiga lembaga kepolisian dituntut menjaga citra positif lembaga dengan cara pembenahan dan peningkatan kualitas Sumber Daya Manusia (SDM) dan penegakan integritas aparat.

Kata Kunci : Demokrasi, Reformasi, Komunikasi Politik, Polri.

\section{Pendahuluan}

Topik artikel ini berusaha mengkaji kinerja komunikasi politik Kepolisian Republik Indonesia (selanjutnya Polri) dengan proposisi bahwa kendatipun kepolisian adalah lembaga (penegak) hukum, kinerjanya -melalui aktivitas komunikasi- dapat menimbulkan pengaruh sosiologis dan (juga) politik, baik pada skala lokal, nasional maupun regional bahkan global. Selain itu, jika merujuk pada pemikiran Peter Berger \& Thomas Luckmann dimana realitas dibangun secara social, maka kinerja Polri sesuai dengan tugas pokoknya yakni menciptakan ketertiban umum dan menjaga keamanan- tentu tidak terartikulasikan di dalam ruang hampa, melainkan di tengah-tengah masyarakat yang aktif dan dinamis inilah yang dimaksud dengan aspek sosiologis dan politik. Karena Polri memiliki aspek sosio-politis ini, maka citra lembaga penjaga keamanan masyarakat ini senantiasa menjadi sorotan publik.

Melansir berita harian umum Republika edisi Jumat 21 Juli 2017 yang memberitakan hasil survey antikorupsi oleh Polling Centre Indonesia Corruption Watch (ICW) terdapat fakta bahwa 50\% masyarakat yang pernah berhubungan dengan kepolisian menyatakan pernah diminta uang atau hadiah secara tidak resmi. Survei yang dilaksanakan dalam periode April dan Mei 2017 di 34 provinsi, 177 Kabupaten/Kota, 212 desa/kelurahan di seluruh Indonesia dengan total responden 2.235 orang (HU. Republika 21 Juli 2017) ini menggambarkan bahwa persepsi masyarakat terhadap kepolisian masih menganggap lembaga ini koruptif. Selain hasil survey ICW, buruknya citra polri juga tercermin dari hasil survey Transparency International Indonesia (TII) menyatakan, kepolisian menjadi institusi dengan tingkat suap tertinggi. Menurut Manajer Riset dan Kebijakan Transparency, Frenky Simanjuntak, praktek penyuapan di kepolisian mencapai 40 persen. Jumlah ini dihitung berdasarkan rasio total transaksi responden dan pelaku bisnis terhadap institusi kepolisian dengan transaksi suap rata-rata mencapai $\mathrm{Rp}$ 2,3 juta (http://www.transparansi.or.id)

Jika menggunakan pemikiran konstruksi realitas sosial dari Berger dan Luckmann dimana kesadaran itu selalu intensional karena ia selalu terarah pada objek dan karena manusia hanya memiliki kesadaran tentang sesuatu (fenomena); maka kesadaran masyarakat tentang Polri yang koruptif, dapat dipahami mengingat manusia memiliki kesadaran tentang dunia kehidupan sehari-harinya saat berhubungan dengan kepolisian sebagaimana yang dipersepsinya. Dalam konteks ini, menjaga realitas Polri di mata masyarakat sebagai sebuah entitas lembaga yang memiliki citra positif menjadi sebuah keniscayaan.

Dalam rezim pasca orde baru, seperti halnya lembaga-lembaga lain, Polri telah melakukan banyak reformasi baik secara administrative maupun secara sosio-politis. Prestasi dan kinerja Polri saat ini jauh sangat baik jika 
dibandingkan dengan jaman sebelum reformasi. Namun demikian, seperti ditunjukkan dalam hasil survey ICW tersebut, masih saja ada sebagian masyarakat yang berpendapat bahwa image atau citra Polri kian lama kian menurun, terutama karena banyak persoalan internal yang tak terselesaikan.

Di sisi lain, ada juga yang berpendapat bahwa penilaian Presiden atas kinerja Polri perlu diperhatikan dengan serius, walaupun dalam hal ini penulis berpendapat, sebagus apapun penilaian presiden terhadap kinerja Polri, tetap saja Polri harus memiliki sensitivitas social dengan memerhatikan penilaian masyarakat, dan pada titik inilah tuntutan agar Polri berusaha memperbaiki citra lembaga tidak lagi terelakan.

\section{Pertanyaan Penelitian}

Tulisan ini mencoba mengkaji tentang bagaimana kinerja komunikasi politik Polri senantiasa bersinggungan dengan ranah sosiologis dan politis. Sebagai bagian dari studi, terdapat beberapa issue yang pernah dihadapi Polri yang berkaitan dengan aspek-aspek sosiopolitis seperti issue pemakaian Jilbab bagi Polisi Wanita (Polwan), dan tuntutan sebuah LSM tentang urgensi administrative Polri dalam mengelola Surat Ijin Mengemudi (SIM). Dua issue ini tidak akan pernah muncul pada jaman orde baru, tetapi dengan sangat gambling menyeruak pada era reformasi. Berdasarkan paparan di atas, untuk lebih mengarahkan tulisan maka pertanyaan utama kajian ini adalah "bagaimana kinerja komunikasi politik Polri pada era reformasi?"

\section{Metodologi Kajian}

Paradigma penelitian dalam artikel ini adalah deskriptif kualitatif dengan tipe metode pengumpulan data berupa desk research, dimana data dikumpulkan dengan cara mempelajari berbagai data dari sumber tulisan berupa dokumen baik hard copy maupun online. Data kemudian dianalisis dengan melandaskan pada konsep-konsep komunikasi politik.

Pengertian Desk Research adalah mengumpulkan dan menganalisis informasi yang sudah ada baik tertulis maupun online berupa dokumen, tulisan di media massa, atau artikel ilmiah yang dipublikasikan di Jurnal dan juga melalui internet, "Gathering and analyzing information, already available in print or published on the internet"

(http://www.businessdictionary.com/def inition/desk-research.html).

Dalam kajian ini, data diperoleh dari makalah staf ahli Polri yang disampaikan pada rapat tertutup tetapi diijinkan penulisnya untuk dikutip, artikel jurnal, dan tulisan tentang sejarah Polri di website resmi Polri serta beberapa artikel di media massa.

\section{Landasan Teoretis IV.1. Konstruksi Sosial}

Teori konstruksi sosial lahir dari pemikiran dua ilmuwan Sosiologi yaitu Peter L Berger dan Thomas Luckmann, di dalam buku mereka yang terkenal dengan judul "The Social Construction of Reality: A Treatise in the Sociology of Knowledge". Asumsi utama teori ini adalah bahwa realitas merupakan hasil ciptaan manusia kreatif melalui kekuatan konstruksi sosial terhadap dunia sosial di sekelilingnya, (reality is socially constructed). Itu sebabnya, Individu yang menjadi komponen masyarakat Indonesia, menjadi penentu dalam mengkonstruksi tentang Polri sesuai dengan kehendaknya. 
Istilah konstruksi sosial atas realitas didefinisikan sebagai proses sosial melalui tindakan dan interaksi dimana individu menciptakan secara terus-menerus suatu realitas yang dimiliki dan dialami bersama secara subyektif (Basrowi, Sukidin, 2002: 204).

Secara rinci asumsi-asumsi dasar dalam teori konstruksi sosial atas realitas adalah:

a. Realitas merupakan hasil ciptaan manusia kreatif melalui kekuataan konstruksi sosial terhadap dunai sosial di sekelilingnya.

b. Hubungan antara pemikiran manusia dan konteks sosial tempat pemikiran itu timbul, bersifat berkembang dan dilembagakan.

c. Kehidupan masyarakat itu dikonstruksi secara terus menerus.

d. Membedakan antara realitas dengan pengetahuan. Realitas diartikan sebagai kualitas yang terdapat di dalam kenyataan yang diakui sebagai memiliki keberadaan (being) yang tidak bergantung kepada kehendak kita sendiri. Sementara pengetahuan didefinisikan sebagai kepastian bahwa realitas-realitas itu nyata (real) dan memiliki karakteristik yang spesifik.

Merujuk pada asumsi dasar tersebut, maka konstruksi sosial atas realitas Polri dapat dimaknai sebagai hasil ciptaan manusia kreatif yang ada di masyarakat Indonesia melalui kekuatan konstruksi social di sekelilingnya, dimana hubungan antara pemikiran tentang Polri dan konteks social tersebut berkembang secara dinamis dan dilembagakan. Hal ini menjelaskan mengapa terjadi pergeseran dinamis konstruksi social atas realitas Polri yang berbeda antara Polri jaman Orde Baru dan jaman reformasi sekarang ini. Konteks social politik rezim yang berkuasa pada kedua orde ini sangat berbeda, sehingga wajar jika Polri pun dimaknai secara berbeda oleh masyarakat saat ini.

\section{IV.2. Komunikasi Politik}

Pengertian komunikasi politik menurut Denton dan Woodwar dalam buku karya Brian McNair, adalah "pure discussion about the allocation of public resources (revenues), official authority, (who is given the power to make legal, legislative and executive decision), and official sanctions (what the state rewards or punishes) (McNair 2007: 3). Definisi ini relevan untuk menegaskan posisi lembaga Polri sebagai official authority, karena kedudukannya sebagai lembaga negara yang diberi kewenangan/ otoritas peniuh untuk mengamankan negara.

Lebih jauh Denton dan Woodward menyatakan bahwa komunikasi politik sebagai "The intentions of its senders to influence the political environment", dalam konteks ini, dapat dipahami bahwa Polri sebagai lembaga negara yang bertindak mewakili pemerintah dapat menyampaikan pesan-pesan politik dengan tujuan memengaruhi lingkungan politik yang kondusif bagi keamanan masyarakat.

Kemudian dinyatakan juga oleh Denton \& Woodward bahwa untuk membuat komunikasi menjadi politis faktor krusialnya bukan terletak pada sumber pesan tersebut, melainkan pada isi dan tujuan komunikasi tersebut. Maka dalam konteks kinerja komunikasi politik Polri dalam percaturan politik nasional sepanjang era reformasi, bukan soal sumber pesan politiknya (apakah itu berasal dari kapolri, presiden, anggota DPR, dan 
lain-lain), tetapi lebih tergantung pada apa isi pesan yang ingin disampaikan Polri pada masyarakat dan apa tujuan pesan tersebut. Artinya, secara ideal, siapapun yang menjadi kepala Polri, pesan-pesan politik untuk membangun situasi keamanan yang kondusif tetap harus menjadi concern utama Polri dalam melaksanakan komunikasi politiknya.

Dalam kaitan ini, penulis ingin menggali ingatan pembaca dengan kasus yang dikenal dengan "Cicak versus Buaya" dimana dalam kasus tersebut, banyak pesan-pesan politik muncul dan disampaikan oleh banyak actor di lembaga kepolisian. Sepanjang proses hukum berlangsung, pesan-pesan politik saling berseliweran dari dua lembaga yang berseteru yakni KPK dan Polri. Kedua lembaga berusaha saling melempar pesan dengan tujuan mempengaruhi opini public atas kasus yang terjadi. Jika dicermati lebih mandalam, isi pesan tersebut pada intinya bertujuan untuk memengaruhi opini public bahwa Polri bersih dari kasus korupsi begitupun KPK berusaha meyakinkan public bahwa justru terjadi tindak pidana korupsi di lembaga tersebut.

Maka tidak salah jika Brian McNair menyatakan bahwa komunikasi politik merupakan kegiatan politik, karena didalamnya terdapat penyampaian pesan yang bercirikan politik oleh aktor-aktor politik kepada pihak lain yang dijalankan sehari-hari oleh masyarakat maupun para elit. Ini artinya, karena kegiatan komunikasi politik sifatnya adalah kegiatan seharihari, maka kegiatan tersebut dapat diamati, dicatat, dihitung dan dipelajari dengan kata lain, kegiatan tersebut bersifat empiris karena dilakukan secara nyata dalam kehidupan sosial. $\begin{array}{ccc}\text { Dalam perspektif ilmu } & \text { politik, } \\ \text { pengertian } & \text { komunikasi } & \text { politik }\end{array}$ dijelaskan sebagai salah satu fungsi dan tujuan struktur politik, yaitu struktur yang ada pada masyarakat dan struktur yang ada pada pemerintah, yakni mencakup: 1) Fungsi Suprastruktur/ penguasa/pemerintah berupa a) Komunikasi politik, b) rekrutmen politik, c) sosialisasi politik, d) pengatur politik dan 2) Fungsi Infrastruktur/rakyat yang mencakup: e) Agregasi kepentingan serta f) Artikulasi kepentingan. (Budiardjo, 1977: 163164). Fungsi komunikasi politik juga diartikan sebagai fungsi untuk menghubungkan pikiran politik yang hidup dalam masyarakat (infra struktur) dengan kehidupan politik pemerintah (supra struktur). Bahkan semua fungsi sistem politik tersebut hakekatnya adalah komunikasi politik, karena tidak ada satupun dari fungsi-fungsi tersebut yang tidak dilakukan melalui fungsi komunikasi.

Hal ini sejalan dengan apa yang disampaikan Gabriel A. Almond dalam bukunya 'The Politics of The Development Area' (1960: 45), bahwa all of the functions performed in the political system, political socialization and recruitment, interest articulation, interest aggregation, rule making, rule application, and rule adjudication, are performed by means of communication.

Dalam persepektif Ilmu

Komunikasi, komunikasi politik merupakan suatu proses komunikasi yang secara konseptual diadopsi dari formula klasik Harold Lasswell, yaitu: Siapa? Mengatakan Apa? Dengan Saluran- (Saluran) Apa? Kepada (Dengan) Siapa? Dengan Akibat (Akibat) Apa? Jika merujuk pada formula Lasswell, komunikator politik atau siapa penyampai pesan dalam 
komunikasi politik dapat terdiri dari: 1) Politisi (baik yang ada di eksekutif maupun legislative), 2) kaum Profesional (akademisi, advokat, jaksa, akuntan, dokter, dan lain-lain), 3) Aktivis 4) Opinion Leader 5) Pressure Group 6) NGO dan 7) Lobbyist.

Sedangkan pesan apa yang disampaikan, dalam konteks komunikasi politik biasanya menyangkut pembicaraan-pembicaraan yang berkaitan dengan soal-soal a) kekuasaan, b) pengaruh dan c) otoritas. Bentuknya bisa macam-macam, seperti: a) pernyataan resmi/tidak resmi dari pemerintah melalui media massa atau media lainnya, b) pendapat / komentar para tokoh pemerintahan pada berbagai forum yang berkaitan dengan kepentingan masyarakat, c) penyampaian pesan politik oleh rakyat terhadap penguasa, berupa penyampaian tuntutan (misalnya dalam bentuk surat di media massa, demo ke DPR/D atau ke kantor pemerintahan, dll)

Penyampaian pesan (politik) dari komunikator (politik) dalam komunikasi politik dapat memiliki kegunaan sebagai berikut:

a. Merupakan arena untuk menyampaikan informasi serta forum untuk menciptakan minat publik yang membahas apa saja informasi yang telah diterima masyarakat.

b. Komunikasi politik menciptakan ruang yang memberi kesempatan masyarakat untuk ikut ambil bagian dalam proses pengambilan keputusan

c. Komunikasi sebagai instrumen untuk menciptakan pendidikan sosial bagi warga masyarakat guna mewujudkan masyarakat terdidik yang berpandangan luas, intelek dan bijaksana.

Adapun saluran komunikasi politik, secara konvensional terdiri dari: $\begin{array}{lcr}\text { komunikasi } & \text { massa, } & \text { komunikasi } \\ \text { interpersonal } & \text { dan } & \text { komunikasi } \\ \text { organisasi, } & \text { bahkan } & \text { dengan }\end{array}$ perkembangan teknologi komunikasi dan informasi, saluran media digital virtual seperti social media kini juga digunakan secara masiv sebagai saluran komunikasi politik. Ketiga bentuk komunikasi politik di atas, dapat terjadi dalam dua pola, bisa down ward communication (biasanya dari pemerintah kepada rakyatnya) ataupun up ward communication (dari masyarakat kepada penguasa).

\section{IV.3. Kepolisian Negara Republik Indonesia (Polri)}

Setelah tadi dijelaskan tentang dua perspektif utama yang memandu analisis artikel ini yakni teori konstruksi social atas realitas dan konsep komunikasi politik, maka untuk melengkapi kajian pustaka perlu juga dipahami sedikit tentang Polri.

Kepolisian Negara Republik Indonesia adalah Kepolisian Nasional di Indonesia, yang bertanggung jawab langsung di bawah Presiden. Polri mengemban tugas-tugas kepolisian di seluruh wilayah Indonesia. dipimpin oleh seorang Kepala Kepolisian Negara Republik Indonesia (Kapolri), tugas pokok Kepolisian Negara Republik Indonesia adalah memelihara keamanan dan ketertiban masyarakat; menegakan hukum, dan memberikan perlindungan, pengayoman, dan pelayanan kepada masyarakat.

Agar dalam pelaksanaan tugastugas kepolisian dapat berjalan dengan baik, Kepolisian Negara Republik Indonesia diberikan wewenang secara umum oleh Undang-undang, yakni:

- menerima laporan dan / atau pengaduan; 
- membantu menyelesaikan perselisihan warga masyarakat yang dapat menggangu ketertiban umum;

- mencegah dan menanggulangi tumbuhnya penyakit masyarakat;

- mengawasi aliran yang dapat menimbulkan perpecahan atau mengancam persatuan dan kesatuan bangsa;

- mengeluarkan peraturan kepolisian dalam lingkup kewenangan administratif kepolisian;

- melaksanakan pemeriksaan khusus sebagai bagian dari tindakan kepolisian dalam rangka pencegahan;

- melakukan tindakan pertama di tempat kejadian;

- mengambil sidik jari dan identitas lainnya serta memotret seseorang;

- mencari keterangan dan barang bukti;

- menyelenggarakan Pusat Informasi Kriminal Nasional;

- mengeluarkan surat izin dan/atau surat keterangan yang diperlukan dalam rangka pelayanan masyarakat;

- memberikan bantuan pengamanan dalam sidang dan pelaksanaan putusan pengadilan, kegiatan instansi lain, serta kegiatan msyarakat;

- menerima dan menyimpan barang temuan untuk sementara waktu.

Terdapat kesadaran kepolisian bahwa lembaga ini tidak mungkin mampu menangani kejahatan sendirian. Keterbatasan sumber daya, materi, anggaran dan sebagainya menuntut kepolisian untuk bermitra dengan masyarakat dan bersama-sama masyarakat memecahkan masalah yang terjadi. Dua hal pokok inilah, yaitu Kemitraan (partnership) dan Pemecahan Masalah (problem solving) menjadi tiang utama konsep community policing atau sering diistilahkan sebagai "Polisi Masyarakat" yang digunakan
Polri dalam melaksanakan tugastugasnya.

Pengertian community policing mengutip dari The United States Department of Justice yang menyatakan bahwa "Community Policing is, in the essence, a collaboration between the police and the community to identifies and solves community problem. With the police no longer the sole guardian of law and order, all members of community become active allies in the effort to enhance the safety and quality of neighborhoods." (Polisi Masyarakat pada prinsipnya adalah sebuah kerjasama antara polisi dan masyarakat untuk mengidentifikasi dan menyelesaikan permasalahan masyarakat, dimana polisi tidak lagi menjadi satu-satunya penjaga ketertiban, namun melibatkan seluruh masyarakat sebagai mitra dalam usaha meningkatkan keamanan dan kualitas hidup lingkungan). (Bureau of Assistance Justice dalam buku "Understanding Community Policing, A frame Work for Action", 1994, The U.S Department of justice.).

\section{Diskusi \& Analisis}

Selain pijakan konseptual komunikasi politik di atas, fenomena komunikasi politik Polri juga dapat dianalisis dari aspek sosiologis. Kinerja komunikasi politik Polri terutama dalam aspek hubungan antar lembaga sapat dicermati pada beberapa kali kasus yang ramai menjadi perbincangan public di media antara lain komunikasi politik Polri dengan Dewan Perwakilan Rakyat (DPR) atau Polri dengan Komisi Pemberantasan Korupsi (KPK). Secara sosiologis, hal ini dapat merujuk pada pernyataan Dennies Peck dan Clifton Bryan yang menyatakan bahwa sosiologi adalah penafsiran pengalaman 
sosial (an interpretation of social experience). Dan social experience itu terjadi atau muncul melalui interaksi seseorang dengan orang lain, satu kelompok dengan kelompok lain "as people take one another into account as each behave toward the other." Dari interaksi bersifat personal ini, sosiologi melangkahkan perhatiannya kepada sistemic units of interaction within social groups, social relations and social organizations." Dalam konteks inilah hubungan dan interaksi antar lembaga seperti Polri dengan lembaga lainnya menemukan legalitas sebagai objek kajian sosiologi: Governments, corporations, and school systems to such territorial organizations as communities or to the schools, factories and churches ... that components of communities, are also concerned with social aggregates, or populations, in their institutional organizations. (Dennies L. Peck and Clifton D. Bryant, "The Sociological Perspective", dalam Clifton D. Bryant and Dennies L. Peck, (eds.), 21th Century Sociology: A Reference Handbook 2007: 2)

Dalam perspektif politik, lebih jauh Gidden, sosiolog terkemuka menyatakan bahwa (ilmu) politik, dalam taraf paling minimal, menaruh perhatian terhadap "the means whereby power is used to affect the scope and content of the governmental activities" (cara-cara bagaimana kekuasaan digunakan untuk mempengaruhi lingkup dan isi aktivitas-aktivitas pemerintahan). Bahkan Gidden menambahkan bahwa politik: is a contested concept and the sphere of the political may range well beyond that of government itself. The anti-war movement, .... is a social movement with political goals, as are many of the groups, networks and organizations (such those composed of environmentalists or feminists) that are discussed elsewhere in this book. (Anthony Giddens, Sociology, Revised and Updated with Phiplip W. Sutton 2009: 988).

Dengan mempertimbangkan kedua definisi di atas, jelas sekali kepolisian, sebagai salah satu lembaga negara bersangkutan secara sosiologis dan politik -terutama ketika mengartikulasikan diri sesuai dengan tugas-tugas pokoknya- di tengahtengah masyarakat.

Bahkan, secara sosiologis, kepolisian bukan saja harus berinteraksi dengan sesama lembaga pemerintahan, melainkan juga dengan anggota-anggota masyarakat, baik sebagai warga "pasif" maupun warga aktif yang mengorganisasikan diri. Sementara secara politik, sebagaimana definisi Giddens, penggunaan kewenangan absah yang dimiliki kepolisian (untuk melaksanakan tugas) akan dinilai secara kritis oleh seluruh elemen politik bangsa. Misalnya, sejauh mana wewenang yang diberikan undangundang kepada kepolisian telah digunakan secara proporsional.

Pemikiran secara teoretis ini menemukan pertautan pragmatis dalam kehidupan social politik, salah satunya nampak dari adanya gugatan Koalisi Masyarakat Sipil untuk Reformasi Polri (KOREKSI) terkait UU No. 2 Tahun 2002 tentang Polri kepada Mahkamah Konstitusi (MK). Penulis mencermati bahwa baik secara sosiologis maupun politik, para penggugat merasakan ada yang "salah" di dalam kinerja Polri.

Terkait Gugatan LSM KOREKSI ini, Fachry Ali, salah satu anggota penasehat ahli Kapolri dalam makalahnya yang bertajuk "Lingkungan Non-Legal Seputar POLRI-KOREKSI" 
memaparkan bahwa landasan argumentasi para penggugat diawali dengan konsep Perdana Menteri Inggris (1834-35), Sir Robert Peel dalam membangun kepolisian modern Inggris. Akan tetapi, dalam pandangan pengggugat, konsep ideal itu tidak terwujud di dalam kinerja kepolisian Indonesia -walau sudah berumur hampir 200 tahun. Inilah yang mereka nyatakan:

Di Indonesia terlihat adanya keterputusan yang nyata antara doktrin kepolisian dan masyarakat. Pasca Reformasi, kepolisian yang seharusnya merupakan bagian dari masyarakat (sipil) untuk mengurus masyarakat, berjalan sendirian meninggalkan masyarakat. Bahkan sebaliknya, jika mencermati temuan lembaga-lembaga riset dan media terkemuka tergambar bahwa kepolisian dipersepsikan sebagai salah satu bagian dari penyakit atau masalah bagi masyarakat.

Pada titik ini, siapapun yang ingin mengembalikan kepolisian kepada amanat konstitusinya atau berharap ada perubahan di institusi kepolisian perlu untuk melihat lebih jauh disain atau struktur kepolisian Indonesia. Tidak tertutup kemungkinan bahwa permasalahan yang terjadi di kepolisian Indonesia pasca Reformasi sebagaimana yang terjadi hari ini akibat adanya kesalah mendasar dalam memahami tugas dan fungsi kepolisian sebagaimana yang dimaksud oleh konstitusi. Salah satu bentuk kesalahan tata kelola tersebut adalah memberikan kewenangan kepada kepolisian untuk menyelenggarakan registrasi dan identifikasi kendaraan bermotor serta mengurus surat izin mengemudi (SIM). Padahal, jika melihat konsep dasar kepolisian sebagaimana yang dimaksud konstitusi, kewenangan itu tidak ditemukan. Melalui UU Kepolisian dan UU Lalu Lintas dan Jalan Raya secara tiba-tiba dan salah kaprah kepolisian diberikan kewenangan untuk mengurus hal-hal teknis tersebut. Akibatya, fungsi dan tugas utama kepolisian untuk melindungi, mengayomi, melayani masyarakat serta menegakkan hukum menjauhi konstitusi. Masyarakat tidak pernah terlayani dan penegakan hukum kerap disalahgunakan. Bahkan dengan kewenangan yang inkonstitusional tersebut, kepolisian dipersepsikan sebagai salah satu episentrum korupsi. (Surat Para Penggugat kepada Ketua Mahkamah Konstitusi, 1 Juli 2015, hlm. 6, dalam makalah Fachry Ali berjudul: "Lingkungan Non-Legal Seputar POLRIKOREKSI" yang 
dipresentasikan di Jakarta,

19 Agustus 2015.)

Dari paragraf-paragraf yang dikutip nampak dalam persepsi penggugat seakan-akan kepolisian bertindak salah. "Kesalahan" tersebut pada mulanya berpijak pada fakta "teknikal". Yakni ketidaksesuaian antara tugas utama kepolisian — sebagai penjaga keamanan dan ketertiban- dengan wewenang pengurusan administrasi kenderaan bermotor dan surat izin mengemudi. Tetapi makin jauh deskripsi para penggugat nampak memasuki hal-hal yang makin sensitif. Dalam kalimat terakhir paragraf terbawah - mereka bahkan menyatakan bahwa kepolisian telah menjadi "episentrum korupsi". Sehingga berdasarkan itu, para penggugat melihat hal yang lebih fundamental, yakni telah terjadi kesalahan desain dan UU Kepolisian.

Menautkan fakta ini dengan perspektif sosiologi komunikasi politik, penulis lebih melihat pada aspek lain yang jauh lebih dari yang nampak ke permukaan, bahwa jika kepolisian tidak pernah terlibat konflik dengan Komisi Pemberantasan Korupsi (KPK), apakah gugatan ini akan lahir? pemikiran nakal ini malah jadi semakin liar ketika penulis menduga bahwa gugatan tersebut kemungkinan besar tidak datang dari orang-per-orang atau lembaga-lembaga yang sekarang tampil sebagai penggugat, melainkan, dari kelompok-kelompok yang, secara teoretis, diorganisasikan oleh para "kompetitor" kepolisian dengan menggunakan atau mengatasnamakan kelompok Lembaga Swadaya Masyarakat (LSM) sehingga secara social politis dapat terlihat seolah gugatan muncul dari masyarakat bahkan dari grassroot.
Layaknya sebuah LSM, para penggugat berasal dari orang-per-orang yang menaruh perhatian terhadap persoalan kemasyarakatan. Karena itu, sangat mungkin mereka ini berasal dari kalangan terpelajar. Dan secara kelembagaan, pihak-pihak yang masuk menjadi penggugat adalah lembaga yang mempunyai reputasi sosial-budaya yang mumpuni: YLBHI dan Pemuda Muhammadiyah. YLBHI, sudah dikenal secara umum, adalah lembaga pembela demokrasi dan hak-hak asasi manusia yang telah berkinerja dengan nama baik sejak masa Orde Baru (1966-1998). Sementara Pemuda Muhammadiyah adalah organisasi sosial keagamaan yang berinduk kepada Muhammadiyah. Masyarakat paham betul, organisasi ini terkenal bersih dan selalu waspada terhadap godaan politik. Dalam Muktamarnya yang berlangsung di Makassar, publik telah dibuat terkesan karena ketertibannya. Dan, tak asa secuilpun isue tentang money politics yang biasanya mewarnai dalam setiap muktamar suatu organisasi social politik di negeri ini.

Artinya, para penggugat ini, sejauh yang bisa dicermati, tidak mempunyai cacat etik pada tingkat publik. Pertanyaannya, mengapa kemudian mereka harus menggugat UU Polri dalam hal wewenang administrasi kendaraan bermotor dan izin mengemudi yang sama sekali bukan menjadi kepentingannya? Hal inilah yang menurut penulis, lahirnya gugatan terhadap Polri datang justru dari "kompetitor" yang secara teoretik, dalam perspektif komunikasi politik, memanfaatkan lembaga-lembaga bereputasi untuk menjadi media penyampai "pesan". Kendati kedua lembaga ini, YLBHI dan Pemuda Muhamadyah tidak memiliki relevansi 
dengan hal-hal bersifat administrative seperti soal pengadaan SIM tadi, tetapi secara teoretis, sebagaimana dinyatakan Giddens di atas, para penggugat ini adalah kelompok-kelompok masyarakat yang aktif dan menaruh perhatian kepada masalah-masalah kemasyarakatan -sejajar dengan aktivis lingkungan atau pelindung hakhak perempuan. Karena itu, juga secara teoretis, bisa disimpulkan bahwa gugatan mereka adalah penyaluruan energi sosial yang terdorong dari sikap atau sifat aktivisme mereka.

$$
\text { Secara konseptual, LSM }
$$

KOREKSI ini memang dapat dikategorikan sebagai Non-Government Organization (NGO) yang notabene merupakan komunikator politik, maka penulis berpendapat bahwa para penggugat ini adalah bagian kecil dari kaum terpelajar pada umumnya yang berharap banyak terpenuhinya hasrat akan keadilan (sense of justice), terutama yang semakin menguat pada era reformasi (pasca Orde Baru).

$$
\text { Salah satu manifestasi }
$$

keterpenuhan sense of justice itu adalah KPK, dimana dalam konteks ini, banyak masyarakat yang memiliki pengalaman negative saat berinteraksi denan lembaga kepolisian, terdera oleh rasa putus asa yang akut terhadap tak terpenuhinya sense of justice. Dam itu telah menyebabkan mereka meletakkan harapan setinggi-tingginya kepada kinerja KPK dalam memberantas korupsi. Dan, dilihat dari persepektif komunikasi politik, dengan melihat tindakannya yang tak pandang bulu, mereka melihat KPK sebagai jantung harapan masa depan Indonesia. Secara kontradiktif, di tengah tingginya harapan mereka kepada lembaga anti koruspsi ini, tiba-tiba kepolisian terlibat konflik dengan KPK, maka dalam perspektif mereka, konflik dengan KPK adalah identik dengan menusuk jantung mereka sendiri.

Untuk menghasilkan efek komunikasi politik yang positif, dengan adanya gugatan ini, Polri nampaknya tidak bersikap resistensi, namun sebaliknya menjadikan gugatan sebagai kritik untuk meningkatkan posisi sosiologis lembaga kepolisian dalam hati masyarakat Indonesia. Kendati bersikap seperti ini memang tidak mudah, mengingat di sisi lain sebagai sebuah korp yang absah mengunakan kekerasan (legitimate vilonce) berdasarkan undang-undang, penulis mencermati dari beberapa fenomena politik yang terjadi, nampak jelas Polri adalah entitas politik yang paling siap menyesuaikan diri di dalam sistem demokrasi.

Tiga contoh lain tentang kinerja komunikasi politik Polri yang patut dicermati misalnya, pertama, demonstrasi tanggal 4 November 2016 dan dan tanggal 21 Februari 2017 yang dikenal dengan "demo 411 dan 212" yang berlangsung secara damai. Walaupun dalam konteks ini, Presiden mempunyai peran tertentu, yaitu melakukan dialog langsung dengan tokoh-tokoh lintas agama dan tokoh masyarakat, nampak jelas peran Polri yang sudah terbiasa dengan keriuhan publik di ruang terbuka tetap sangat menentukan kekondusifan situasi dan kondisi demonstrasi tersebut. Kedua, kegiatan pemilu yang senantiasa diikuti oleh mobilisasi massa. Pemilu dalam konteks ini bukan saja siklus lima tahunan, melainkan juga hampir bersifat bulanan. Ini terjadi karena berbagai daerah/kota dan propinsi melakukan pemilu di masing-masing daerah. Sudah pasti, setiap pemilu ini ditandai oleh kobilisasi massa. Dan, berkat peran 
Polri sebagai Pengaman Pemilu, sebagian besar public event ini berlangsung dengan damai. Ketiga, dalam iklim demokrasi, orang per orang maupun kelompok absah melakukan unjuk rasa, terutama secara fisik. Dan fenomena unjuk rasa ini berlangsung hampir setiap hari, walau berlangsung di tempat-tempat berbeda. Dalam kenyataannya, sebagian besar ribuan unjuk rasa itu berakhir dengan damai.

Dengan indikator tersebut inilah penulis menyatakan bahwa Polri adalah the guardian of democracy (penjaga demokrasi). Dalam konteks inilah managemen sumberdaya manusiamenjadi aspek terpenting untuk diberi perhatian khusus oleh Polri. Bahwa dengan kian menyadari posisi Polri di dalam sistem politik demokrasi dan secara undang-undang bertugas menjaga keamanan di dalam negeri, maka fokus terbesar pembinaan SDMnya harus lebih mengarah kepada kemampuan personil memberikan daya tanggap kreatif terhadap democracyrelated socio-political issues (masalahmasalah sosial-politik yang lahir karena pelaksanaan demokrasi).

Ini perlu disadari benar oleh Polri karena sebagai satuan penegak hukum dan penjaga keamanan dalam negeri di dalam sistem demokrasi, Polri akan secara terus-menerus berhadapkan dengan persoalan-persoalan kemasyarakatan. Alasan pokoknya adalah bahwa sistem politik demokrasi mensyaratkan seseorang atau sekelompok orang yang berhasrat mempunyai kekuasaan harus atas dasar persetujuan rakyat. Dan untuk memperoleh persetujuan rakyat, proses pembujukan terjadi. Yang paling kentara di dalam proses ini adalah interaksi tokoh atau golongan yang terorganisasi (partai) dengan massa meningkat. Sementara tokoh dan partai membutuhkan persetujuan rakyat, pihak terakhir ini kian merasa mandiri atau otonom. Otonomi rakyat ini inilah yang terungkap di dalam pernyataanpernyataan publik. Semakin rakyat merasa otonom (karena kesadaran bahwa pemimpin tak akan absah memperoleh kekuasaan tanpa dukungan mereka), maka akan kian terangterangan mereka menyampaikan perasaannya. Ungkapan perasaan yang bersifat kolektif dan massif inilah yang berpotensi timbulnya pergerakanpergerakan diluar kontrol.

Oleh karena Polri oleh undangundang ditugaskan untuk menetramkan gejolak-gejolak sosial-politik yang timbul sebagai akibat dari unjuk rasa massif, kolektif dan terbuka ini, maka sesungguhnya korp ini berhadapan langsung dengan pelajaran-pelajaran sosial-politik. Dalam arti kata lain, hanya dengan melakonomi sebagai the guardian (penjaga) hiruk pikuk unjuk rasa yang berlangsung secara terusmenerus itu, Polri dihadapkan dengan berbagai "pelajaran". Pertama, tentang crowd psychology (psikologi kerumunan massa). Orang per orang di dalam kerumunan tersebut berpotensi mengalami depersonalisasi. Yaitu kehilangan kemampuan mengendalikan diri dan cenderung lebur dalam suasana perasaan bersama. Kedua, corak tentang cara massa mengungkapkan perasaannya (melalui kata maupun tindakan fisik). Tiga, aneka asal-usul kelompok. Di sini Polri telah dan akan berhadapan dengan kaum petani, mahasiswa, pelajar, buruh, kaum intelektual atau gabungan dari berbagai kelompok tersebut. Keempat, tipe-tipe kepemimpinan baik yang turut turun ke jalan maupun yang berada di belakang layar. Kelima, latar belakang sosial- 
ekonomi dan budaya kelompokkelompok masyarakat.

Yang terpenting ditekankan di sini adalah bahwa di dalam sistem demokrasi, Polri akan terus-menerus berada di tengah-tengah massa untuk memetik pelajaran yang tidak terdapat di dalam buku atau bangku pendidikan. Sekaligus dengan itu, Polri menjadi avant garde (kelompok terdepan) dalam menghadapi isue-isue sosial-politik semacam itu.

Karena itu, penulis cenderung menyatakan bahwa kinerja Polri di dalam sistem demokrasi penuh dengan bibit-bibit pengetahuan sosial-budaya dan politik. Hampir bisa dipastikan bahwa tidak ada kesatuan lain yang mempunyai kesempatan emas semacam ini. Maka, penulis berpendapat Polri perlu mengarahkan salah satu fokus managemen SDM-nya pada kemampuan pengenalan, perumusan dan pemecahan masalah-masalah sosialpolitik ini. Kemampuan ini akan sangat berguna bukan saja untuk Polri, melainkan juga untuk memelihara kelanjutan demokrasi secara damai. Jika Polri mengarahkan perhatian kepada pembentukan kemampuan SDM untuk memberikan respon terhadap isue-isue ini, maka satuan ini akan menjadi spearhead (ujung tombak) pengetahuan sosial-budaya dan politik yang lahir melalui proses pelaksanaan demokrasi.

Masih dalam konteks komunikasi politik, Polri juga pernah menghadapi persoalan krusial terkait dengan konteks keagamaan. Tentang hal ini, harian Republika pernah menurunkan berita secara berturut-turut dalam suatu pekan di tahun 2014 tentang jilbab bagi Polisi Wanita (Polwan), sebuah isue keagamaan yang menyangkut institusi penegak hukum ini. Isue jilbab - yang tampil ke publik melalui pernyataan
Jendral Polisi Sutarman beberapa hari setelah dikukuhkan Kepala Kepolisian Republik Indonesia (Kapolri) - ini kembali hangat bersamaan dengan dua kejadian: Hari Bayangkara Polri 1 Juli dan keputusan DPR menetapkan anggaran belanja untuk penutup kepala Polwan itu. Berita Republika ini jelas merupakan "desakan" bersifat keagamaan agar Polri tak lagi ragu "memerintahkan" Polwan Muslimat menggunakan jilbab.

Di sisi lain, secara kontradiktif "desakan" berbeda disampaikan Jennie M. Xue dan Michael J. Rahardjo tentang keharusan Polri menjaga stabilitas pluralisme masyarakat Indonesia berdasarkan "sekularisme". Dalam artikelnya "What the Year of the Horse Means?" (The Jakarta Post, 2 Feb. 2014), mereka berkata “ ... bagaimanapun juga, Indonesia adalah negeri sekular berdasarkan Pancasila. Juga, dalam Islam sunni, fatwa seperti yang dikeluarkan Majlis Ulama Indonesia (MUI) tidak mengikat, melainkan hanya merupakan pendapat para ahli. Dan telah menjadi kewajiban polisi dan tentara menjaga perdamaian."

Menghadapi dilema seperti ini, untuk menghasilkan efek komunikasi politik yang baik, bagaimana seharusnya Polri bersikap? Di mana Polri harus berada?

Menganalisis persoalan ini, peneliti berpendapat bahwa tekanan pertanyaan pertama terletak pada fragmentarisme pandangan antar agama dan, bahkan, di dalam satu agama, yang kerap berujung bukan saja pada faksionalisme, melainkan "kekerasan" terhadap yang lain. Tidak aneh jika M. Xue dan Rahardjo di atas meletakkan "harapan besar" kepada polisi dan tentara dalam hal ini. 
Jika mengacu pada aspek legal, melalui UU No 2/2002, tanggungjawab polisi terfokus kepada keamanan dalam negeri, maka secara sosiologis, polisi lebih berada di tengah dinamika masyarakat. Pada saat yang sama, melalui UU itu pula posisi dan tempat Polri diperjelas, yakni sebagai alat negara, dan karena Indonesia bukanlah negara agama, maka Polri berkewajiban tegak di atas segala agama. Walaupun nyatanya hal tersebut sangat dilematis mengingat setiap anggota polisi memeluk agama masing-masing, dan karena Islam adalah agama mayoritas, secara praktis sebagian besar anggota polisi adalah Muslim dan harus tunduk pada ketentuan Islam, tanpa harus meminta persetujuan negara. Inilah, menurut penulis, alasan yang mendorong suara yang dikumandangkan Republika tentang jilbab di atas.

Lantas apakah kemudian dilema ini menimbulkan "konflik loyalitas" di kalangan polisi? Mencermati issue ini dalam konteks komunikasi politik, kembali terjadi pengulangan seperti halnya saat terjadi konflik KPK dan Polri dalam kasus "Cicak VS Buaya", yaitu terjadinya saling lempar pesanpesan politik melalui media massa, dimana masing-masing pihak berupaya memperoleh dukungan opini public. Perkembangan kasus Jilbab ini ternyata cukup bernas, karena polisi tersosialisasi dan berkembang sebagai sebuah korp yang melayani kepentingan negara, maka polisi tidak sampai mengalami konflik loyalitas. Artinya, Polri wajib melindungi setiap warga negara tanpa melihat kelompok dan agamanya, sehingga pandangan resmi inilah yang tersosialisasikan ke dalam struktur kesadaran anggota polisi.
Di sisi lain, dalam kasus Jilbab ini penulis mencermati, terutama karena adanya keanekaragaman ekstrims kelompok-kelompok masyarakat tidak memiliki pandangan yang sama dengan polisi. Yang muncul ke permukaan, terutama dalam framing media massa adalah fakta kelompok-kelompok masyarakat Indonesia lebih meyakini gagasan dan aturan yang berada di luar negara. Mereka yang menganut "pandangan umum Ke-Islam-an", misalnya, akan lebih memperhatikan fatwa MUI tentang ketentuan-ketentuan keagamaan daripada peraturanperaturan negara. Anggota-anggota "faksi" tertentu di dalam Islam, contoh lainnya, lebih tunduk atau loyal pada gagasan, pandangan, dan keyakinan yang disosialisasikan kepada mereka secara spesifik daripada peraturanperaturan negara.

Sepanjang semua berjalan damai, tak ada masalah serius dihadapi polisi. Tetapi, tidak jarang juga terjadi perbedaan pandangan dan keyakinan tersebut kerap diungkapkan dalam bentuk kekerasan atas nama agama. Sebuah status Facebook pukul 5 pagi, Jumat, 11 April 2014, misalnya, menyatakan: "Jadi sekarang, yang lagi berperang untuk membela kesucian agama-Nya menjadi bodoh semuanya dalam pandangan anda. Kalau begitu, biarlah anda yang lebih pintar. Wassalam!" Pernyataan ini adalah kesimpulan penulis status Facebook itu, setelah berdebat sejak Kamis malam sebelumnya.

Penulis mencermati, kata "perang" di sini bermakna sebenarnya, yakni kekerasan yang absah menurut pandangan keagamaan penulis status itu terhadap mazhab Islam tertentu. Pengalaman sepanjang masa reformasi ini, pandangan semacam ini telah kerap 
diterjemahkan ke dalam kekerasan. Dalam konteks inilah, menurut saya, letak kepelikan posisi sosiologis, sosial budaya dan keagamaan Polri. Ini terjadi karena negara —sebagai lembaga "sekular" - tidak mempunyai otoritas atas pandangan-pandangan keagamaan, dan karena alat negara, maka Polri juga tak memiliki otoritas yang sama.

Menghadapi

"tantangan"

sekelompok masyarakat yang cenderung "ekstrim" ini nampaknya Polri memilih strategi komunikasi politik soft power —sebagai pengejawantahan diskresi Polri. Manifestasinya adalah pembentukkan "Gugus Tugas Sosial-Budaya dan Keagamaan". Dengan "gugus tugas" ini, Polri secara teoretis bisa mencapai nilai strategis tersendiri.

Landasan legal atas pemikiran ini adalah, pertama, berdasarkan UU No. 2/2002 Polri adalah penanggungjawab keamanan dan ketertiban dalam negeri. Karena itu, posisi Polri tepat di tengahtengah dinamika masyarakat. Kedua, posisi ini strategis bagi Polri untuk mengembangkan secara lebih konseptual dan bermakna tindak "diskresi". Yaitu, pengambilan keputusan dan tindakan berdasarkan dinamika kemasyarakatan yang metoda penanganannya tidak atau belum ada di dalam tertib tindakan resmi. Ketiga, berkaitan kuat dengan poin kedua di atas, dengan gugus tugas ini Polri mempunyai kesempatan luas memperoleh bahan-bahan atau materi dinamika dan pergolakan kemasyarakatan. Karena itu, Polri adalah satu-satunya satuan pemelihara keamanan yang mempunyai potensi pengembangan pengetahuan masyarakat secara akademik dan, akhirnya, menjadi "pusat pengetahuan sosial-budaya". Keempat, pengetahuan akademik atas dinamika dan pergolakan kemasyarakatan ini akan memberikan otoritas absah bagi Polri sebagai pemecah persoalan kemasyarakatan dalam kaitannya dengan masalah budaya, sosial dan keagamaan. Kelima, kemampuan memecahkan persoalan kemasyarakatan dengan "diskresi" akan menimbulkan fase baru peranan Polri, karena pendekatan legitimate violence (kekerasan yang absah) dalam proses penegakan hukum menjadi tereduksi secara signifikan. Keenam, keamanan dan ketertiban yang ditegakkan Polri melalui "diskresi" ini bukan saja akan membuat negara lebih terjaga, melainkan juga akan menjadi model bagi korp polisi di negara-negara lain.

\section{Simpulan \& Saran}

Dari paparan di atas, penulis menyimpulkan beberapa hal terkait kinerja komunikasi politik Polri, terutama berkaca pada beberapa kasus seperti gugatan LSM KOREKSI dan tuntutan pemakaian Jilbab bagi Polwan, sebagai berikut:

1. Kendati dalam beberapa issue krusial, presiden acap kali "turun tangan" tetapi berbagai indicator menunjukkan keterbiasaan dan keprofesionalan Polri dalam mengatasi keriuhan massa di ruang public telah memosisikan Polri sebagai the guardian of democracy (penjaga demokrasi).

2. Dari berbagai sikap Polri dalam menghadapi dilema, nampak bahwa Polri adalah satu-satunya entitas lembaga negara pemelihara keamanan yang mempunyai potensi pengembangan pengetahuan masyarakat secara akademik dan, akhirnya, menjadi "pusat pengetahuan sosial-budaya. 
3. Kinerja komunikasi politik Polri dalam berbagai proses politik pada era reformasi telah jauh mengalami perubahan paradigma yang membuat posisi Polri tegak sebagai actor politik yang mampu bertindak sekaligus baik sebagai komunikator politik maupun komunikan politik.

\section{Saran}

Dari kajian singkat ini, penulis menyarankan agar Polri dapat terus

\section{DAFTAR PUSTAKA}

Ali, Fachry, "Lingkungan Non-Legal Seputar POLRI-KOREKSI" makalah yang dipresentasikan di Jakarta, 19 Agustus 2015.

Almond, Gabriel A. 'The Politics of The Development Area', 1960, Routledge, London\&New York

Berger, L peter. 1990. "Tafsir Sosial Atas Realitas" Jakarta: Lembaga penelitian, pendidikan, dan penerangan ekonomi dan sosial hal 1.

Budiardjo, Miriam, 1977, "Dasar-dasar Ilmu Politik", Balai Pustaka, Jakarta.

Bureau of Assistance Justice, 1994, The US Department of justice. , "Understanding Community Policing, A frame Work for Action", USA.

Giddens, Anthony, 2009, Sociology, Revised and Updated with Phiplip W. Sutton Cambridge: Polity Press, hlm. 988.

Harian Umum Republika edisi Jumat 21 Juli 2017

Ismail, Chaerudin; 1998, Polisi Pengayom VS Penindas, Jakarta, Jakarta Citra

Jurnal/Dokumen Jurnal Kepolisian. 2011. Agus Raharjo dan Angkasa, .Profesionalisme Polisi dalam meningkatkan profesionalitasnya dan juga mengembangkan kualitas SDMnya sehingga Polri dapat menjadi sumber pengetahuan dan budaya bagi masyarakat. Hal ini dapat dicapai Polri dengan cara banyak membangun kemitraan riset pengembangan inovasi terutama yang berkaitan dengan masalah social politik yang ada di masyarakat.

penegakan hukum, Fakultas Hukum Universitas Jenderal Soedirman. Jurnal Kepolisian. 2013.

Masyarakat Transaparansi Indonesia, "Transparency: Polisi Miliki Potensi Suap Tertinggi”. Http://www.transparansi.or.id

McNair, Brian, 2007, An Introduction to Political Communication, $4^{\text {th }}$ edition, Routledge, London \& New York.

Nitibaskara, Tubagus Ronny Rachman; 2001, Ketika Kejahatan Berdaulat - Sebuah Pendekatan Kriminologi, Hukum dan Sosiologi, Jakarta, Peradaban.

Peck, Dennies L. dan Bryant, Clifton D. "The Sociological Perspective", dalam Clifton D. Bryant and Dennies L. Peck, (eds.), 21th Century Sociology: A Reference Handbook Thounsand Oaks, California: Sage Publication Inc, 2007, hlm. 2.

Sukidin, Basrowi, " Metode Penelitian Kualitatif Perspektif Mikro", Surabaya, Insan Cendekian, 2002. hlm. 204

Walker, Samuel; 1992, The Police in America : An Introduction, New York, MC Graw Hill. www.polri.go.id 
https://jurnalsrigunting.wordpress.com/ 2012/09/12/lay-out-nkp-polrikritis-dan-berwawasankeilmuan/ https://id.wikipedia.org/wiki/Kepolisian _Negara_Republik_Indonesia

\section{Biodata Penulis}

Dr. Evie Ariadne Shinta Dewi, M.Pd, lahir di Bandung, 1 April 1967 meniti pendidikan dasar, menengah dan $\mathrm{S} 1$ sampai S3 di kota Bandung. Sejak tahun 2002 menjadi PNS Dosen dan mengampu mata kuliah Komunikasi Politik, Komunikasi Strategis, Opini Publik, PR Politik, Social Change, Hubungan Industrial, dan Pendidikan Kewarganegaraan, di Fakultas Ilmu Komunikasi Universitas Padjadjaran Bandung. Pernah menjdai anggota KPU Kota Bandung periode 2008-2013 dan masuk pada 14 calon anggota KPU RI periode 2013-2018. Karya akademik yang pernah dihasilkan antara lain disertasi tentang "PR Politik KPU pada Pemilu Legislatif 2009”, serta berbagai hasil kajian dalam ranah komunikasi politik Pemilu/Pilkada. Beberapa tahun terakhir melakukan riset dengan dana dari Dirjen Dikti berupa kajian fenomenologi seputar HIV-AIDS. Selain sebagai akademisi, peneliti dan kolumnis, juga aktif sebagai konsultan Public Relations untuk lembagalembaga pemerintahan. Pernah menjadi wartawan dan penulis lepas media Lokal Bandung antara tahun 1986-1991, dan hingga sekarang tetap menulis artikel antara lain di HU. Pikiran Rakyat dan Koran Sindo. Aktif menjadi pengurus ICMI Orwil Jabar, Masika ICMI dan HIPIIS Jabar. 